\title{
Protective Effect of Microbubble Aeration and Dietary Probiotics BALSS on Survival and Immunity of White Leg Shrimp (Litopenaeus vannamei) Postlarvae against Acute Low Salinity Stress
}

\author{
Shima Bhaskara Ayuningrum', Indah Istiqomah", Rustadi Rustadi', Bambang Triyatmo', Alim Isnansetyo', Wiratni \\ Budhijanto² \& Deendarlianto Deendarlianto 3 \\ ${ }^{1}$ Master Program in Fisheries Science, Department of Fisheries, Faculty of Agriculture, Universitas Gadjah Mada, Yogyakarta, Indonesia \\ 2Department of Mechanical Engineering, Faculty of Engineering, Universitas Gadjah Mada, Yogyakarta, Indonesia \\ 3Department of Chemical Engineering, Faculty of Engineering, Universitas Gadjah Mada, Yogyakarta, Indonesia \\ *Corresponding author: e-mail: indah_ist@ugm.ac.id
}

Submitted 07 November 2019 Revised 05 March 2020 Accepted 30 June 2020

\begin{abstract}
Survival rate and immunity of white leg shrimp ((Litopenaeus vannamei) postlarvae against acute salinity stress were evaluated in indoor experimental trials. The research was conducted with $2 \mathrm{x} 2$ factorial design with two levels of aeration (microbubble and macro bubble) and two levels of diet (with and without probiotics) resulting four treatments in triplicate: application of microbubble with gut probiotics (MiP), without gut probiotics (MiC), and macro bubble with gut probiotics $(\mathrm{MaP})$ and without probiotics $(\mathrm{MaC})$. White leg shrimps measuring $7.6 \mathrm{~g}$ were maintained in the tanks for 60 days and fed five times a day at a dose of 5\% biomass. Harvested shrimp were tested for low salinity stress (5 ppt) for 3 hours. Glucose level, total protein, bactericidal activity, natural agglutination, phenoloxidase, respiratory burst, and superoxide dismutase activities in the hemolymph and the shrimp survival rate (SR) were analyzed before and after the stress tests. Although all examined parameters remained the same between groups before the stress test, significant differences were found among them after the stress test. Microbubble aeration obtained stabilization of hemolymph glucose level, best survival rate, bactericidal activity, and agglutination activities. No significant effect was resulted by the dietary probiotic treatments, but the interaction with aeration treatments revealed the importance to compensate shrimp survival rate when microbubble aeration is unavailable.
\end{abstract}

Keywords: White leg shrimp; microbubble; probiotic; immunity; survival; stress test; acute low salinity

\section{INTRODUCTION}

Global demands for white meat has lead to the rapid growth of the world production of aquatic resources in the past decades of which aquaculture industries have played a decisive role (Jespersen et al., 2014). Shrimp, along with other seafood commodities such as tuna, lobster and cephalopods are in high demand (FAO, 2016). Although shrimps are highly sensitive to environmental stressors, most of them are cultured in open ponds located along the coast which are very susceptible to unpredicted environmental changes or fluctuations (Pusceddu et al., 2011). Litopenaeus vannamei growth optimum at salinity levels of 15-20 ppt or more (Rosas et al., 2001; Gao et al., 2016). Sudden changes in water salinity, mainly due to rain, can drastically affect the metabolism, growth, molting, and shrimp survival as well as the biochemical and physiological parameters of shrimp in response to stress and even cause death (Shekhar et al., 2013; Pillai \& Diwan, 2002). Accordingly, shrimp ponds management is essensial, especially to guarantee that the shrimp in optimal conditions to resists against various stressors.

Aeration systems are important factors in intensive shrimp culture. Various types of aerators have been developed and used in shrimp farming, including blowers, vertical pumps, and propeller aeration systems (Lara et al., 2016). Aerators that produce micro-sized air bubbles called microbubbles have advantages over conventional air blowers, such as the long lifetime in liquid and its high gas solubility into the liquid (Liu et al., 2013, Agarwal et al., 2011). A microbubble generator device developed by Deendarlianto et al. (2015) has been demonstrated to support the tilapia farm in high stocking densities (Budhijanto et al., 2017). The application of the microbubble generator device in shrimp farming is an attraction to study.

Shrimp dependence on non-specific immune system attracts many researchers to evaluate the effect of probiotics on shrimp. Probiotics are beneficial bacteria that able to increase feed digestibility, thereby increasing the growth (Wang et al., 2019) or reduce the discharge of organic matter derived from the feces (Santos, 2014). The existence of immunomodulation by probiotics in shrimp was first raised by Rengpipat et al. (2000). Administration of probiotics Bacillus spp. at the dose of $1.5 \times 10^{6} \mathrm{cfu} / \mathrm{g}$ of diet enhances shrimp juvenile resistance to environmental stressors such as salinity and or temperature abnormalities, formalin, chlorine and ammonia (Arpanahi et al., 2014). The level of glucose and cortisol hormone in the probiotics treated groups were also lower than to controls, indicating the potential benefit in reducing stress in shrimp (Arpanahi et al., 2014). Probiotic BALSS is a mixture of Bacillus sp., Aeromonas sp., Lactococcus sp., Streptococcus sp., and Saccharomyces sp. we isolated from the fish intestine. The bacteria were confirmed on the strong enzymatic activities, non-pathogenic characters (Rohman et al., 2018) and the ability to promote the growth of tilapia (Istiqomah et al., 2018).

In the present study, we aimed to examine the effect of microbubble aeration, dietary probiotic and the combination of Litopenaeus vannamei juvenile resistance against acute 
salinity stress. shrimps were maintained with microbubble aeration and dietary probiotic for two months before the acute salinity stress test. Shrimp resistance against the stressor was determined based on the glucose level, total protein, bactericidal activity, natural agglutination, phenoloxidase, respiratory burst, and superoxide dismutase activities in the hemolymph, and the shrimp survival rate (SR).

\section{MATERIALS AND METHODS}

\section{Shrimp}

Shrimps (7.6 g) were obtained from a shrimp hatchery center in Yogyakarta region and were acclimatized for one week before the experiment. Shrimps were randomly stocked in a 900 I tanks of seawater at a density of 113 shrimps/container with a constant inlet water discharge of $0.028 \mathrm{l} / \mathrm{s}$ and salinity $25 \mathrm{ppt}$. A completely randomized design was used in this experiment with $2 \times 2$ factorial of two-level aerations (microbubble and blower) and twolevel probiotics (non-probiotic and probiotic diet) in three replicates. Shrimps were cultured for 60 days in tanks aerated using a microbubble or blower. The control and probiotic supplement feeds were given $5 \%$ of biomass/day (five times a day). Hemolymph at the initial experiment was taken and tested for glucose level to ensure that shrimps were at the same physiological condition (Figure 1).

\section{Microbubble generator}

The microbubble generator is one tool that can increase dissolved oxygen in the water. The principle of the microbubble generator is the pressure of water flow and atmospheric air into the pump and water flow out with micro-sized air bubbles. Bubbles produced from microbubbles measuring 50-200 $\mu \mathrm{m}$. The number of bubbles with a diameter of $50 \mu \mathrm{m}$ and $100 \mu \mathrm{m}$ every 300 bubbles and measuring more than 100-200 $\mu$ m with 50 bubbles at $33.33 \mathrm{I} \mathrm{min}^{-1}$ water flow and $0.2 \mathrm{I} \mathrm{min}^{-1}$ airflow (Deendarlianto et al., 2015). The schematic diagram of the microbubble generator is presented in Fig. 1. Nine of the tanks were operated with the microbubble generator (WP 106 water pump, 85 Watt) and nine with blowers (Atman HP-12000, 60 Watt). Microbubble generator and blower airflow were equals to $0.068 \mathrm{I} \mathrm{s}^{-1}$.

\section{Probiotic}

Gut probiotics BALSS (Bacillus sp. PCP1, Aeromonas sp. JC18, Lactococcus sp. JAL12 Staphylococcus sp. JC20 and Saccharomyces sp. FNCC3012) were activated in molasses medium (fish meal $5 \mathrm{~g} \mathrm{l}^{-1}$, molasses $3 \mathrm{~g} \mathrm{l}^{-1}$, monosodium glutamate $1 \mathrm{~g} \mathrm{l}^{-1}$ and distilled water) at $30{ }^{\circ} \mathrm{C}$ for $24 \mathrm{~h}$. A commercial feed with a composition of protein $35 \%$ and lipid $6 \%$ was used as a basal diet. The suspensions of probiotics with concentration $10^{6} \mathrm{cfu}$ (g diet) ${ }^{-1}$ in molasses medium were sprayed on the feed. The control shrimps (non-probiotic) were fed with basal diet spread with molasses medium without the probiotics.

\section{Shrimp culture}

Shrimps were maintained with two-level of aerations (blower and microbubble) and fed with two-level of diets (probiotics and non-probiotic). Shrimps were maintained for $60 \mathrm{~d}$ in a tank $\left(1 \times 1 \times 1 \mathrm{~m}^{3}\right)$ and fed at $5 \%$ body weight five times a day (at $07.00 ; 10.00 ; 13.00 ; 16.00$ and 19.00 h). At the end of the experiment (before stress test), the hemolymph from each tank was sampled with a syringe using anticoagulants (10\% sodium citrate) in the ventral sinus section of shrimp. $0.5 \mathrm{ml}$ hemolymph was taken from 5 shrimps from each tank and transferred into a microtube.

\section{Stress test}

A salinity stress test was conducted for $3 \mathrm{~h}$ at the end of the treatments (day-60). Eight shrimps from each tank were collected and transferred to tanks $(30 \times 60 \times 35 \mathrm{~cm})$ with low salinity 5 ppt for the stress test, which lasted for 3 h. survival of shrimp was evaluated at the end of the experiment. The hemolymph of shrimp was taken to test for glucose level, total protein plasma, antibacterial serum activity, natural agglutination, phenoloxidase, respiratory burst, and superoxide dismutase (SOD) activities.

\section{Observation Parameters}

Hemolymph glucose level

Hemolymph glucose was measured using the Gluco Test (Gluco Dr). Hemolymph in microtube was taken with capillary and dropped on glucose strip. The result of glucose concentration was read digitally.

\section{Total protein plasma (TPP) test}

Total Protein Plasma (TPP) was measured spectrophotometrically following the procedure of Setyawan (2019). Hemolymph was centrifuged at 1500 rpm for $5 \mathrm{~min}$. Two microliters of serum were added with $798 \mu$ l of distilled water and $200 \mu \mathrm{l}$ of protein test kit (Biorad), then incubated for $15 \mathrm{~min}$. The absorbance of $600 \mathrm{~nm}$ was measured using a spectrophotometer. Previously, a standard curve of protein level was determined by BSA (Bovine Serum Albumin-Merk) at a multilevel concentration of 75; 50; 12.5 and $6.25 \mathrm{mg} / \mathrm{ml}$.

\section{Antibacterial serum activity test}

Antibacterial serum activity was tested by mixing a $5 \mu$ of bacterial suspension of Vibrio harveyi $\left(10^{6} \mathrm{cfu} \mathrm{ml}^{-1}\right)$ and $45 \mu \mathrm{l}$ of hemolymph and incubated for $1 \mathrm{~h}$. Then, the mixture was diluted and dropped on TCBS (Thiosulfate Citrate Bile Salt Sucrose) medium fir 24 of incubation at room temperature. Antibacterial activity of the serum was calculated base on the following equation.

Antibacterial serum activity $=(1$-(number of treatment colonies/number of control colonies)) $\times 100 \%$

\section{Natural agglutination test}

Natural agglutination was measured following the procedure of Purbomartani (2019). $25 \mu$ l PBS was transferred to a microtiter well except in the first well. The first and second well was filled with $25 \mu \mathrm{l}$ serum and stratified dilution. $25 \mu \mathrm{l}$ of the mixture was transferred in the next well, and $25 \mu \mathrm{l}$ antigen was added into all wells, incubated for $1 \mathrm{~h}$ at room temperature. Furthermore, overnight incubation at low temperature and observed a lump formed in the middle well. The agglutination titer value of the sample is the opposite of the last dilution that shown agglutination.

\section{Phenol oxidase (PO) activity test}

PO activity was measured spectrophotometrically following the procedure of Yudiati et al. (2016). $100 \mu \mathrm{l}$ hemolymph was mixed with $100 \mu$ PBS (phosphate Buffer Saline) and 
centrifuged at $7000 \mathrm{~g}$ for $2 \mathrm{~min}$. The pellet was added with $100 \mu \mathrm{l}$ of cacodylate buffer and centrifuged at $7000 \mathrm{~g}$ for 2 min. The supernatant was added with $100 \mu$ of trypsin, incubated for 10 minutes, and mixed with $50 \mu \mathrm{l}$ L-DOPA. The phenoloxidase activity was measured based on the optical density by spectrophotometry (490 nm).

\section{Respiratory burst test}

Respiratory burst activity test was carried out based on the method of Isnansetyo et al. (2016). The $100 \mu \mathrm{l}$ of hemolymph was added with the same volume of 0.25 NBT solution and incubated for $30 \mathrm{~min}$. After that, $50 \mu \mathrm{l}$ of the mixture was transferred in a glass and added 1000 $\mu$ l of N-N Dimethyl Formamide solution, then centrifuged at $3000 \mathrm{rpm}$ for $5 \mathrm{~min}$. The supernatant was transferred to a glass cuvette and absorbance was measured with a spectrophotometer at $540 \mathrm{~nm}$.

\section{Super oxide dismutase (SOD) activity test}

The SOD activity was measured spectrophotometrically by recording the riboflavin by NBT (Nitroblue Tetrazolium). The $40 \mu$ l of hemolymph was homogenized with $160 \mu \mathrm{l}$ Phosphate Buffer (50 mM, pH 7.8) and centrifuged at 12000 for $4 \mathrm{~min}$. The $200 \mu \mathrm{l}$ of supernatant was heated at $65^{\circ} \mathrm{C}$ for $5 \mathrm{~min}$. Finally, $50 \mu \mathrm{l}$ of crude extract added with $50 \mu \mathrm{l}$ NBT buffer and incubated for $2 \mathrm{~min}$. The optical density at 630 $\mathrm{nm}$ was measured using spectrophotometry (Yudiati, 2016).

\section{Shrimp survival rate}

The number of live shrimp was counted after the low salinity stress test for $3 \mathrm{~h}$.

Survival rate $(\mathrm{SR}, \%)=$ live shrimp number/total shrimp number x 100 (Cai et al., 2019).

\section{Statistical analysis}

All data were analyzed by ANOVA (Analysis of Variance) at the significance level of 0.05. A multilevel comparison (DMRT) test was used to examine significant differences among treatments using SPSS IBM 20 software. Before the analysis, all data were analyzed on the normality and homogeneity test.

\section{RESULTS AND DISCUSSION}

\section{Blood glucose}

The value of the glucose level is shown in Figure 1. The glucose level at the initial maintenance was in the same range (62.33-75.33 $\mathrm{mg} \mathrm{dl}^{-1}$ ), and stable at the end of the trial (60 d). Three hours after transferring shrimps to $5 \mathrm{ppt}$, glucose level significantly increased in all treatments except microbubble aeration with gut probiotic.

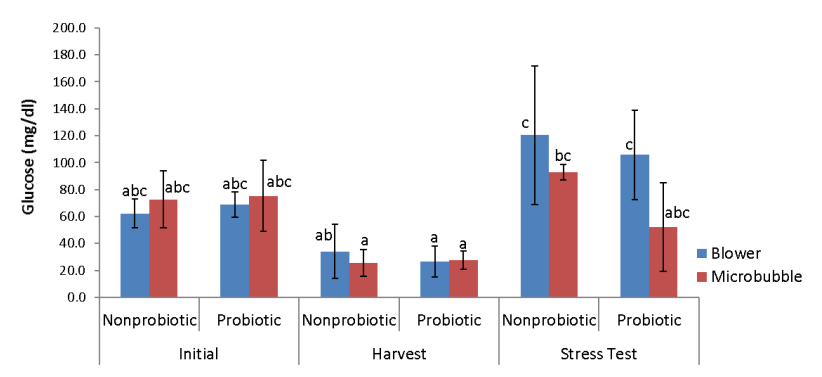

Figure 1. Glucose content (mg/dl) of L. Vannamei.

\section{Shrimp survival}

Results of shrimp survival of acute low salinity stress are shown in Figure 2. The stress resistance showed an interaction between aeration and probiotic factor. Shrimp survival in microbubble aeration and non-probiotic feed treatment significantly $(P<0.05)$ were higher than blower aeration and non-probiotic feed but similar to between micro bubble-gut probiotic and blower-gut probiotics groups.

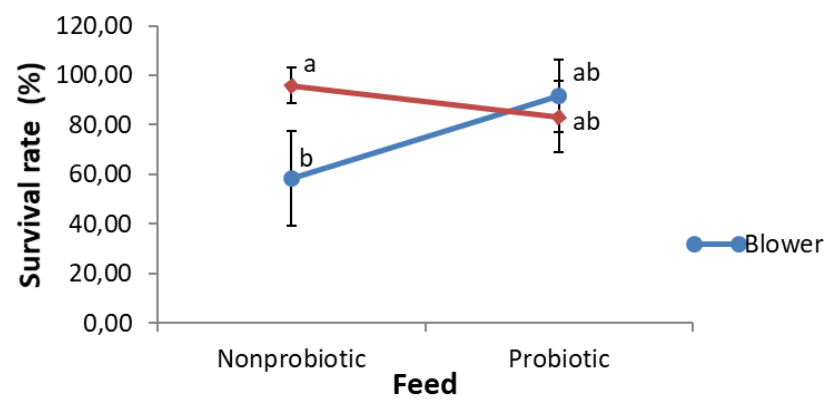

Figure 2. Survival rate (\%) of $L$. Vannamei after stress test.

"Values with different superscripts on the same row show significant differences $(\mathrm{P}<0.05)$.

Total plasma protein

The total protein plasma of all groups remained the same at the end of the experiment (days-60) (Figure 3). The value before and after the stress test was also similar in the range of $70.13-79.89 \mu \mathrm{g} / \mu \mathrm{l}$.

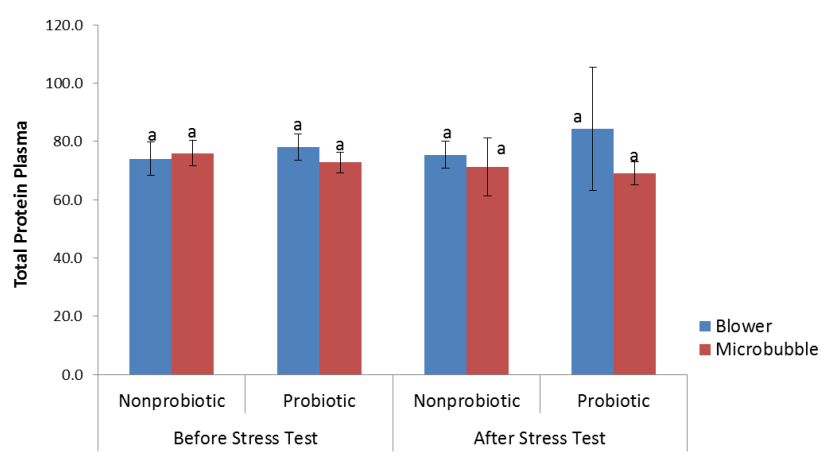

Figure 3. Total protein plasma of L. Vannamei.

"Values with different superscripts on the same row show significant differences $(\mathrm{P}<0.05)$

Serum bactericidal activity

The result of serum antibacterial activity at the end of maintenance (days-60) showed significant differences between treatments (Figure 4). After the stress test, serum antibacterial activity of all treatments significantly increased at various levels. The statistical test indicated that the serum antibacterial activity of microbubble aeration was significantly higher than blower aeration, while probiotic feed treatment no significant difference with non-probiotic feed treatment. 


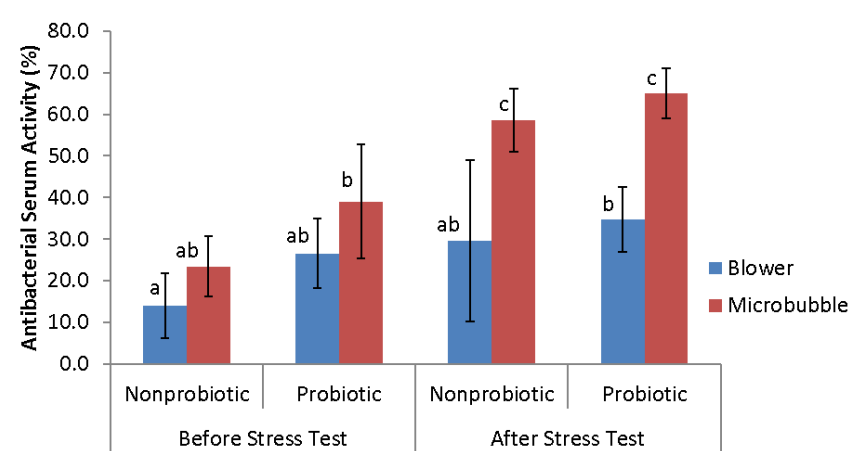

Figure 4. Antibacterial serum activity (\%) of L. Vannamei. "Values with different superscripts on the same row show significant differences
$(P<0.05)$.

\section{Natural serum agglutination}

The result of agglutination activity at the end of the experiment (days-60) showed no significant differences between treatments (Figure 5). After the stress test, agglutination activity was increased in all treatments but remained similar ( $P>0.05)$.

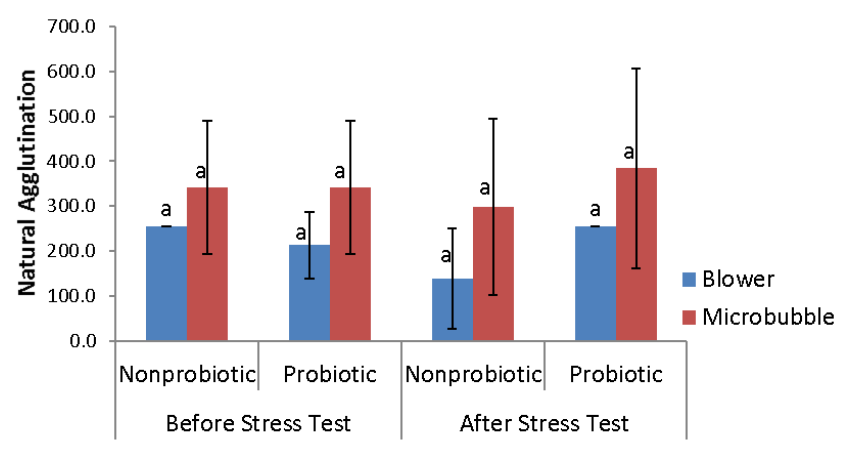

Figure 5. Natural agglutination of L. Vannamei. *Values with different superscripts on the same row show significant differences
$(P<0.05)$.

\section{Phenoloxidase activity}

There was no different phenoloxidase activity between treatment until 2 months of maintenance (Figure 6). The values were increased due to the stress test but remained similar $(\mathrm{P}>0.05)$.

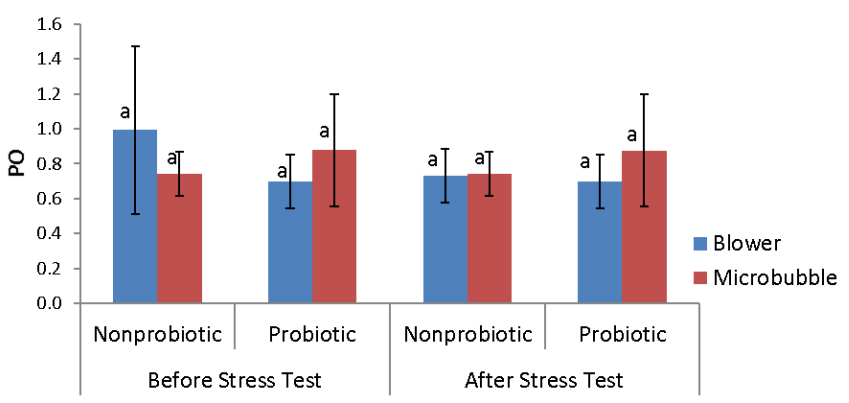

Figure 6. PO activity of L. Vannamei.

*Values with different superscripts on the same row show significant differences
$(P<0.05)$.

Respiratory burst activity

The result of respiratory burst at the end maintenance (days-60) showed no significant difference between treatments (Figure 7). After the stress test, respiratory burst in blower aeration with gut non-probiotic was significantly increased, while in the other treatments were similar.

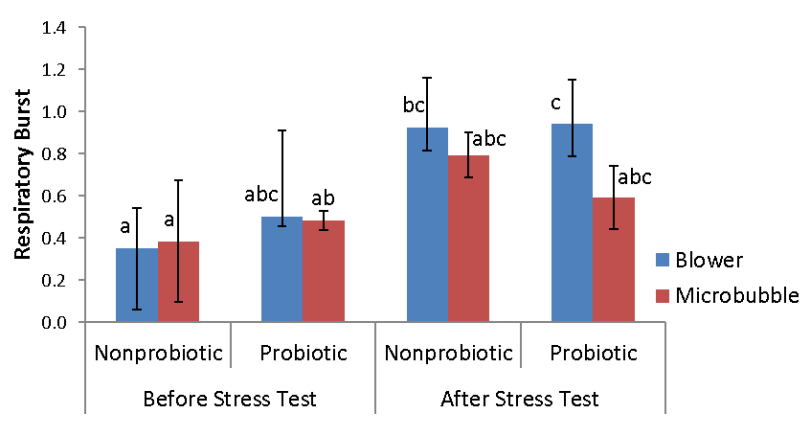

Figure 7. Respiratory burst activity of L. Vannamei.

"Values with different superscripts on the same row show significant differences $(P<0.05)$.

\section{Superoxide dismutase activity}

The result of SOD activity at the end maintenance showed no significant difference between treatments (Figure 8). After the stress test, the SOD activity of all treatments increased but similar between treatments $(P>0.05)$.

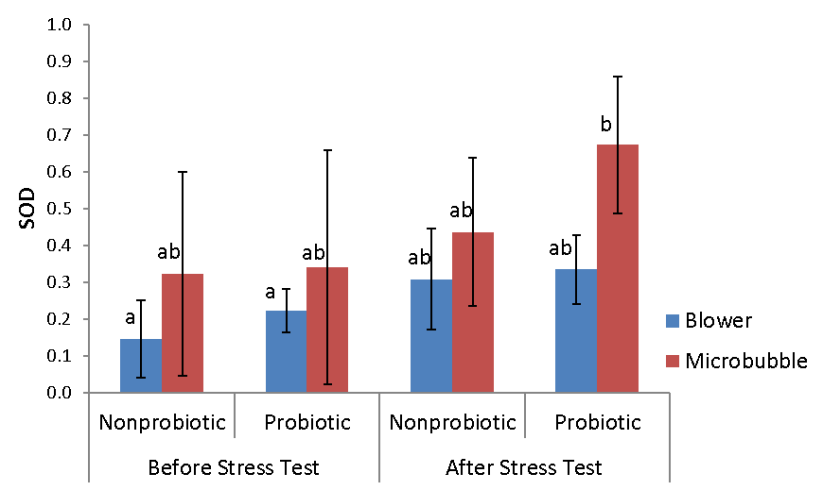

Figure 8. SOD activity of L. Vannamei *Values with different superscripts on the same row show significant differences
$(P<0.05)$.

\section{Discussion}

Salinity is an important abiotic environment affecting the metabolism, survival, osmotic capacity, growth and immune system of Litopenaeus vannamei (Alvarez et al., 2004; Xie et al., 2014). Although it has been reported that low salinity does not affect the white leg shrimp feed convention ratio and growth (Jaffer et al., 2020), it decreased the survival rate (Diaz et al., 2009). We suspect the decrease in survival is related to stress conditions, which could be corrected by the application of water probiotics (Liu et al., 2010).

In the present study, we found that shrimps treated with microbubble aeration and gut probiotics demonstrated a stable hemolymph glucose level within two months of treatment. This result indicated that shrimp have successfully adapted to the environment condition applied. Thereafter, la ow salinity stress test resulted in an increased hemolymph glucose level to more than $160 \mathrm{mg} \mathrm{dl}^{-1}$ in the control groups, indicating the presence of stress response to increase energy to maintain homeostasis defense (Cuzon et al., 2004). The application of microbubble successfully stabilizes the glucose levels (85-100 $\left.\mathrm{mg} \mathrm{dl}^{-1}\right)$, and the 
combination with intestinal probiotics decreases that number to $20-85 \mathrm{mg} \mathrm{dl}^{-1}$. Also, the shrimp adaptation ability in the conditions provided in this study as indicated by the stability of hemolymph glucose level (as mentioned above) shows the hope for shrimp farming with an indoor tank with recirculation system. This result supports the opinion expressed by Suantika et al. (2018). This kind of shrimp farming practice will guarantee a process that is more easily controlled, especially in the aspect of biosecurity which is often complained in open-pond cultivation.

Application of microbubble, probiotic and the combination produced shrimp survival rate (SR) of $60-100 \%$ in the present high-density indoor farming with water recirculation system and low salinity stress. This result is encouraging considering the control group has a lower survival rate (39-78\%). According to Widodo et al. (2011), salinity changes can lead to mortality due to the sudden change in osmoregulation, osmotic pressure, oxygen consumption, and stress levels. In the present study, the higher shrimp survival rate was obtained by microbubble aerated groups related to the presence of more oxygen in the water. According to Deendarlianto et al. (2015), bubbles generated from microbubbles were varied, ranging from 50-200 $\mu \mathrm{m}$. The number of bubbles with a diameter of 50 $\mu \mathrm{m}$ and $100 \mu \mathrm{m}$ each with 200 bubbles and more than $100-200 \mu \mathrm{m}$ with 50 bubbles. with the understanding that smaller bubbles will have more air diffusion areas, the microbial group receives a greater amount of air than the normal aeration group. Interestingly, the combination of micro bubbles-intestinal probiotics has produced SR that similar to the combination of ordinary aeration-intestinal probiotics. It was shown that oxygen is needed for waste respiration and degradation processes, and an effective aeration system is required (Bryand et al., 2006). Here, we speculate the possibility of some probiotics coming out with feces and living in the water. If this happened, oxygen consumption was not only done by shrimp but also by probiotics. Further studies are needed to confirm this phenomenon.

Increased serum bactericidal activity in shrimp due to the application of probiotics was reported by Chiu et al. (2007). However, in the present study, increased serum bactericidal activity was induced by low salinity stress in shrimp reared with MBG with and without probiotics. We suspect that this character arises because shrimp of microbubble treated groups live in comfortable environmental conditions, especially in terms of oxygen content so that they have a good immune system.

Natural agglutination is an immune response to foreign particles or pathogen that enters the body. The immune response is characterized by the binding or clumping of particles by antibody or agglutinin. Agglutination plays an important role in the immune system to fight pathogens (Mitsi et al., 2016). We demonstrated that the application of microbubble and the combination with probiotic enhance the natural agglutination of shrimp hemolymph against low salinity stress. When stress occurs, natural agglutinations were maintained at $2^{8-9}(256-512)$ by the microbubble and probiotic treated groups, while it was only $2^{6-8}(64-256)$ in the control groups.

Phenoloxidase and total protein plasma of all groups in the present study remained stable. Phenoloxidase is an enzyme that plays an important role in the proPO system. Phenoloxidase will oxidize phenol to quinone which then forms a polymer into melanin and plays a role in destroying pathogens Amparyup et al. (2013). In the present study, the shrimp phenoloxidase during maintenance for two months and after low salinity stress tests were similar between treatments $(P>0.5)$. The stable $P O$ values during the experiments in all treatments showed that the treatments in this study did not affect the shrimp PO system. On the other hand, the white leg shrimp total protein plasma (TPP) was stable for two months of maintenance, low salinity stress-induced the TPP value to increase but similar between treatment. This phenomenon is similar to that were demonstrated by Yudiati et al. (2016) who applied various types of immunostimulants to white leg shrimps.

Cellular immunity response observed in this study was respiratory burst and superoxide dismutase (SOD) activities. We found that both parameters were relatively homogeneous between treatments and increased when the shrimps were exposed to low salinity stress. The increase in the activity of the two parameters indicates stress conditions that required more cell energy and was responded by the increasing of cell metabolism and production of free oxygen radicals (Reactive Oxygen Species/ ROS) (Yudiati, 2016; Wulandari, 2017). SOD activity is strongly influenced by the respiratory burst. The SOD values indicated the ability of shrimp neutralize free radicals that able to cause cell damage (Yudiati, 2016). Data of the present study revealed that the aeration system and probiotic did not influence the shrimp respiratory burst and SOD activities.

In conclusion, it is demonstrated that microbubble aeration without or with the application of gut probiotic could improve white leg shrimp L. vannamei resistance against low salinity stress as indicated by the survival rate, hemolymph glucose level, serum bactericidal activity, and natural agglutination. Further investigation on the mechanism by which the immune stress resistance and parameters are improved needs to be investigated.

\section{ACKNOWLEDGMENT}

This research was partially funded by Faculty of Agriculture, Gadjah Mada University, through Hibah Penelitian Dosen (contract number 3184/PN/PG/2017) chaired by Indah Istiqomah and Hibah Unggulan (contract number 1689/ PN/PT/2019) chaired by Rustadi. We would like to thank the Faculty of Agriculture which has provided funding and the opportunity to conduct this research.

\section{REFERENCES}

Agarwal, A., W. Jern Ng \& Yu Liu. 2011. Review: Principle and applications of microbubble and nanobubble technology for water treatment. Chemosphere. 84: $1175-1180$

Alvarez, A.L. I.S. Racotta, O. Arjona \& E. Palacios. 2004. Salinity stress test as a predictor of survival during grows out in pacific white shrimp (Litopenaeus vannamei). Aquaculture. 237: 237-249 
Amparyup, P., W. Charoensapsri \& A, Tassanakajon. 2013. Prophenoloxidase system and its role in shrimp immune responses against major pathogens. Fish \& Shellfish Immunology. 34: 990-1001

Arpanahi, D.A., J. Hojatollah, S. Mehdi \& H.G. Kanani. 2014. The effect of Bacillus probiotics on the growth performance, survival rate and stress resistance of white leg shrimp Litopenaeus vannamei (Boone, 1931) postlarvae. Journal of Fisheries Science \& Technology. 1: 38-50

Bryand, D.L., A.L. Kadilak \& S.R. Pani. 2006. Good Management Practices for Shrimp Farming in Costa Rica. Report Costa Rica Project Center. 144 p

Budhijanto, W., D. Deen, S. Yano \& H. Muhamad. 2017. Application of microbubble generator as low cost and high efficient aerator for sustainable freshwater fish farming. AIP Conference Proceedings. 1840: (1)

Cai Y., Y. Wei, W. Shifeng, G. Weiliang, Li. An, W. Yue, C. Xin, R. Zhuling \& Z. Yongcan. 2019. In vitro screening of putative probiotics and their dual beneficial effect: to white shrimp (Litopenaeus vannamei) postlarvae and the rearing water. Aquaculture. 498: 61-71

Chiu, C. H., Y.K. Guu, C.H. Liu, T.M. Pan \& W. Cheng. 2007. Immune responses and gene expression in white shrimp, Litopenaeus vannamei, induced by Lactobacillus plantarum. Fish Shellfish Immunol. 23 (2): 364-377

Cuzon, G., A. Lawrence, G. Gaxiol, C. Rosa \& J. Guillaume. 2004. Nutrition of litopenaeus vannamei reared in tanks or ponds. Aquaculture. 235: 513-551

Deendarlianto., Wiratni, E.T. Alva, Indarto \& G.W.I. Anggita. 2015. The Implementation of A Developed Microbubble Generator on the Aerobic Wastewater Treatment. IJTech. 6: 924-930

Diaz, F, C. Farfan, E. Sierra \& A.D. Re. 2001. Effects of temperature and salinity fluctuation on the ammonium excretion and osmoregulation of juveniles of Penaeus vannamei. Boone. Mar. Freshw. Behav. Physiol. 34: 93-104

FAO. 2016. The State of World Fisheries and Aquaculture. Rome. 200 p

Gao, W., L. Tianc, T. Huang, M. Yao, W. Hu \& Q. Xu. 2016. Effect of salinity on the growth performance, osmolarity and metabolism-related gene expression in white shrimp Litopenaeus vannamei. Aquaculture Reports. 4:125-129

Jespersen, K.S., I. Kelling, S. Ponte \& F. Kruijssen. 2014. What shapes food value chains? Lesson from aquaculture in Asia. Food Policy. 49: 228-240

Isnansetyo, A., A. Fikriyah, N. Khasanah \& Murwantoko. 2016. Non-specific immune potentiating activity of fucoidan from a tropical brown algae (Phaeophyceae), Sargassum cristaefolium in tilapia (Oreochromis niloticus). Aquacult int. 24: 465-477

Istiqomah, I. Deendarlianto, A. Isnansetyo, Wiratni, Rustadi \& S. Indarti. 2018. Smart aquaculture to improve production of high quality tilapia (Oreochromis sp.) meat in earthen pond: a combination of microbubble aeration system and fish gut probiotic. Asia Pacific Conference on Food Security 2018. Selangor, Malaysia
Jaffer, Y.D., R. Saraswathy, M. Ishfaq, J. Antony, D.S. Bundela \& P.C. Sharma. 2016. Effect of low salinity on the growth and survival of juvenile pacific white shrimp, Penaeus vannamei: A revival. Aquaculture. 515: 734561

Lara, G., K. Dariano, C.A. Paulo, H.P. Luis \& W. Wilson W. 2016. The use of different aerators on Litopenaeus vannamei biofloc culture system: effects on water quality, shrimp growth and biofloc composition. Aquaculture Internasional. 25:147-162

Liu, C., T. Hiroshi, J. Zhang, L. Zhang, J. Yang, X. Huang \& N. Kubota. 2013. Succesful application of shirasu porous glass (spg) membrane system for micro bubble aeration in biofilm reactor treating synthetic wastewater. Separation and Purification Technology J. 103:53-59

Liu, K-F., C-H. Chiu, Y-L. Shiu, W. Cheng \& C-H. Liu. 2010. Effects of the probiotic, Bacillus subtilis E20, on the survival, development, stress tolerance, and immune status of white shrimp, Litopenaeus vannamei larvae. Fish \& Shellfish Immunology 28 (5-6): 837-844

Louis, S., N. Wabete, D. Ansquer, J. Mailliez, M. Pallud, C. Zhang, M. Lindivat, V. Boulo \& D. Pham. 2018. Survival improvement conferred by the Pseudoalteromonas sp. NC201 probiotic in Litopenaeus stylirostris exposed to Vibrio nigripulchritudo infection and salinity stress. Aquaculture. 495: 888-898

Mitsi, E., A.M. Roche, J. Reiné, T. Zangari, J.T. Owugha, S.H. Pennington, J.F. Gritzfeld, A.D. Wright, A.M. Collins, S. van Selm, M.I. de Jonge, S.B. Gordon,J.N. Weiser \&D.M. Ferreira. 2017. Adaptive immunity agglutination by anti-capsular polysaccharide antibody is associated with protection against experimental human pneumococcal carriage. Mucosal Immunology. 10: 385-394

Pillai B.R. \& A.D. Diwan. 2002. Effect of acute salinity stress on oxygen consumption and ammonia excretion rates of the marine shrimp Metapenaeus monoceros. Journal of Crustacean Biology. 1: 45-52

Pusceddu, A., L.D. Patrona \& B. Beliaeff. 2011. Trophic status of earthen ponds used for semi-intensive shrimp (Litopenaeus stylirostris, Stimpson 1874) farming in New Caledonia (Pacific Ocean). Marine Environmental Research. 72: 160-171

Rengpipat, S., S. Rukpratanporn, S. Piyatiratitivorakul \& P. Menasaveta. 2000. Immunity enhancement in black tiger shrimp (Penaeus monodon) by a probiotic bacterium (Bacillus S11). Aquaculture. 191: 271-288

Rohman, A.F., A. Isnansetyo \& I. Istiqomah. 2018. Screening and identification of proteolytic bacteria from the intestine of marine fish. The $8^{\text {th }}$ International Conference of Aquaculture Indonesia: Towards Sustainable Effective and Profitable Integrated Aquaculture Business.Yogyakarta

Rosas, C., G. Cuzon, G. Gaxiola, Y. L. Priol, C. Pascual, J. Rossignyol, F. Contreras, A. Sanchez \& A. V. Wormhoudt. 2001. Metabolism and growth of juveniles of Litopenaeus vannamei: effect of salinity and dietary carbohydrate levels. Journal of Experimental Marine Biology and Ecology. 259: 1-22 
Rustadi., I.P. Sattwika, I. Istiqomah, Deendarliyanto \& Wiratni. 2018. Effect of microbubble aeration on water quality and performance of catfish (Clarias sp.) in intensive aquaculture with varying water depths. The 2nd Scientific Communication in Fisheries and Marine Science (SCiFiMaS), 7-9 May 2018. UNSOED, Purwokerto

Sadatomi, M., K. Akimaro, M. Finimori \& K. Takanao. 2007. An Advanced microbubble and its advantages to a newly developed bubble-jet-type air-lift pump. 19 (4): 323-342

Santos, G. 2014. Probiotics an essential tool in intensive shrimp aquaculture. Biomin. Herzogenburg, Austria. $8 \mathrm{p}$

Shekhar, M.S., J. Kiruthika \& A.G. Ponniah. 2013. Identification and expression analysis of differentially expressed genes from shrimp (Penaeus monodon) in response to low salinity stress. Fish \& Shellfish Immunology. 35: 1957-1968

Setyawan, A. 2019. Fucoidan dari alga cokelat tropis sebagai imunostimulan pada udang vannamei (Litopenaeus vannamei): kajian hematologi, ekspresi gen-gen imun, resistensi terhadap WSSV dan pertumbuhan. Fakultas Pertanian. Universitas Gadjah Mada. Disertasi

Takahashi, B., J.D. Takahashi, L.S. Pilarski, F.A. Sebastiao \& E.C. Urbinati. 2013. Serum bactericidal activity as an indicator of innate immunity in pacu Piaractus mesopotamicus (Holmberg, 1887). Arq. Bras. Med. Vet. Zootec. 6: 1745-1751
Wang, A., C. Ran, Y. Wang, Z. Zhang, Q. Ding, Y. Yang, R.E. Olsen, E. Ringo, J. Bindelle \& Z. Zhou. 2019. Use of probiotics in aquaculture of China - a review of the past decade. Fish \& Shellfish Immunology. 86: 734755

Widodo, A.F., B. Pantjara, N.B. Adhiyudanto \& Rachmansyah. 2011. Performansi fisiologis udang vaname, Litopenaeus vannamei yang dipelihara pada media air tawar dengan aplikasi kalium. J. Ris Akuakultur. 6: 225-241

Wulandari, R. 2017. Pengaruh pemberian probiotik terhadap aktivitas letupan respirasi leukosit dalam darah ikan nila (Oreochromis niloticus). Intek Akuakultur. 1:71-76

Xie, S., L. Tian, Y. Jin, H. Yang, G. Liang \& Y. Liu. 2014. Effect of glycine supplementation on growth performance, body composition and salinity stress of juvenile Pacific white shrimp, Litopenaeus vannamei fed low fishmeal diet. Aquaculture. 418-419: 159-164

Yudiati, E., A. Isnansetyo, Murwantoko, Ayuningtyas, Triyanto \& C.R. Handayani. 2016. Innate immunestimulating and immune genes up-regulating activities of three types of alginate from Sargassum siliquosum in Pacific white shrimp, Litopenaeus vannamei. Fish \& Shellfish Immunology. 54: 46-53. 